\title{
PENGARUH LIKUIDITAS DAN STRUKTUR AKTIVA TERHADAP \\ STRUKTUR MODAL PADA PERUSAHAAN NON KEUANGAN \\ DI BURSA EFEK INDONESIA
}

\section{Hedar Rusman}

Dosen STIE Bisnis Indonesia, Jakarta

\begin{abstract}
This Research aim to get empirical evidence about likuiditas influence to capital structure, to get empirical evidence about asset structure influence to capital structure, to get empirical evidence about likuiditas and asset structure influence to capital structure. Assess is 0.000 meaning likuiditas variable t-sign smaller than value $0,05(0,000<0,05)$ hence $\mathrm{Ha}_{1}$ hypothesis accepted, its meaning alikuiditas variable represent is signifikan to capital structure variable individually or parsial. This means likuiditas have an effect on to capital structure.
\end{abstract}

Keyword: Likuiditas, Structure Asset, Capital Structure

\begin{abstract}
Abstrak: Penelitian ini bertujuan untuk untuk mendapatkan bukti empiris mengenai pengaruh likuiditas terhadap struktur modal, untuk mendapatkan bukti empiris mengenai pengaruh struktur aktiva terhadap struktur modal, untuk mendapatkan bukti empiris mengenai pengaruh likuiditas dan struktur aktiva terhadap struktur modal. Nilai t-sign variabel likuiditas 0.000 artinya lebih kecil dari nilai $\alpha 0,05(0,000<0,05)$ maka hipotesis $\mathrm{Ha}_{1}$ diterima, artinya suatu variabel likuiditas merupakan penjelas yang signifikan terhadap variabel struktur modal secara individual atau parsial. Ini berarti likuiditas berpengaruh terhadap struktur modal.
\end{abstract}

Kata Kunci: Likuiditas, Struktur Aktiva, Struktur Modal 


\section{PENDAHULUAN}

Pada zaman sekarang ini, dunia bisnis sedang memasuki kondisi ekonomi global yang mendorong persaingan bisnis yang sangat ketat antar perusahaan. Hal tersebut mendorong para manajer perusahaan untuk meningkatkan produktivitas kegiatan produksi secara efisien dan efektif. Selain kegiatan produksi, para manajer juga diharuskan meningkatkan produktivitas kegiatan pemasaran, memaksimalkan fungsi-fungsi di dalam perusahaan dan strategi perusahaan. Kegiatan tersebut dimaksudkan untuk mencapai tujuan perusahaan dengan salah satunya adalah mensejahterakan para pemegang saham dan meningkatkan daya saing dalam menghadapi para kompetitornya (Wimelda dan Marlinah 2013). Hal ini juga dilakukan untuk mempertahankan kelangsungan hidup perusahaan atau going concern yang baik untuk kedepannya.

Dalam suatu bisnis umumnya keputusan manajemen untuk membuat keputusan struktur permodalan bertujuan untuk memaksimalkan nilai perusahaan dan hal ini tidak mudah karena meliputi pemilihan utang dan ekuitas untuk menjaga keseimbangan proporsi antara biaya dan keuntungan dari aktivitas tersebut. Pengambilan keputusan yang keliru akan menyebabkan kesulitan keuangan bahkan mengakibatkan kebangkrutan (Sheikh dan Wang 2011). Dengan demikian, manajer perusahaan harus mampu mengambil keputusan yang tepat dalam hal pendanaan untuk mencapai tujuan perusahaan.Keputusan pendanaan yang baik dari suatu perusahaan dapat dilihat dari struktur modal, yaitu keputusan keuangan yang terdiri dari komposisi utang, baik utang jangka panjang maupun utang jangka pendek, serta saham, yang terdiri dari saham biasa maupun saham preferen yang akan digunakan oleh perusahaan. Dalam persaingan usaha yang ketat, perusahaan harus memiliki keputusan pendanaan yang tepat, dimana perlu adanya peran manajer dalam menentukan struktur modal yang paling optimal. Struktur modal yang optimal akan mampu meminimalkan biaya modal yang harus ditanggung perusahaan (Margaretha dan Ramadhan 2010:120).

Masalah pendanaan merupakan bagian yang sangat penting bagi dunia usaha, karena berkaitan dengan kepentingan banyak pihak, seperti kreditur, pemegang saham, serta pihak manajemen perusahaan sendiri. Pendanaan dapat berasal dari internal maupun eksternal. Pendanaan internal dapat berupa laba ditahan serta depresiasi, sedangkan dana yang diperoleh dari sumber eksternal adalah dana yang berasal dari para kreditur, pemegang surat utang (bondholders) dan pemilik perusahaan (Joni dan Lina 2010). Sumber pendanaan yang ada dalam perusahaan umumnya berasal dari modal sendiri maupun dari utang yang dimiliki perusahaan. Perusahaan melakukan pinjaman atau utang karena sifatnya tidak permanen dan biaya pengadaannya lebih murah dibanding dengan menerbitkan saham (Wimelda dan Marlinah 2013). Menurut Nuswandari (2013:93), manajer keuangan sering kali dihadapkan adanya suatu variasi dalam pembelanjaan, dalam arti kadang-kadang perusahaan lebih baik menggunakan dana yang bersumber dari utang (debt) namun kadang-kadang perusahaan lebih baik kalau menggunakan dana yang bersumber dari modal sendiri (equity). Oleh karena itu manajer keuangan perlu mempertimbangkan berbagai faktor yang mempengaruhi struktur modal agar biaya modal rendah, keuntungan perusahaan meningkat dan pada akhirnya dapat memaksimalkan harga saham perusahaan.Menurut Sheikh dan Wang (2011), struktur modal (capital structure) dapat diukur melalui rasio utang (debt ratio). Dimana terdapat faktor-faktor yang memengaruhi struktur modal seperti profitabilitas, ukuran perusahaan, non-debt tax shields, struktur aktiva, kesempatan pertumbuhan, volatilitas laba, dan likuiditas. Sejalan dengan penelitian yang dilakukan oleh beberapa peneliti terdahulu, menunjukkan hasil yang berbeda-beda dan tidak konsisten, maka peneliti termotivasi untuk melakukan penelitian dengan tema yang sama mengenai faktor-faktor 
yang memengaruhi struktur modal di perusahaan. Penelitian ini merupakan pengembangan dari penelitian yang dilakukan oleh Sheikh dan Wang (2011) dengan judul penelitian sebelumnya Determinants of Capital Structure An Empirical Study of Firms in Manufacturing Industry of Pakistan.Berdasarkan latar belakang yang telah diuraikan maka penulis memilih judul "Pengaruh Likuiditas dan Struktur Aktiva Terhadap Struktur Modal Pada Perusahaan Non Keuangan di Bursa Efek Indonesia”.

\section{TINJAUAN TEORI}

\subsection{Pecking Order Theory}

Teori ini pertama kali dikemukakan oleh Gorden Donaldson tahun 1961 dengan penelitian yang berjudul Corporate Debt Capacity. Pecking Order Theory adalah sebuah hirarkhi pendanaan yang dimulai dari laba ditahan, yang diikuti dengan pendanaan utang dan akhirnya pendanaan eksternal modal (Gitman dan Zutter 2012:534). Hal ini berarti bahwa perusahaan cenderung mengutamakan pendanaan dari sumber internal guna untuk membayar dividen dan mendanai investasi. Apabila kebutuhan dana kurang maka akan digunakan sumber dana eksternal sebagai tambahannya. Pendanaan internal diperoleh dari laba atau laba ditahan, sedangkan pendanaan eksternal dapat dilakukan melalui utang atau menerbitkan obligasi. Pilihan terakhir dengan menerbitkan saham baru.

Pecking order theory mengemukakan bahwa perusahaan cenderung mempergunakan sumber pendanaan internal (retained earnings) sebanyak mungkin untuk membiayai proyekproyek di dalam perusahaan. Utang menjadi pilihan kedua setelah sumber pendanaan internal kemudian convertible bond,preferred stock, dan pada akhirnya apabila masih memerlukan dana, perusahaan akan menerbitkan common stock. Hal ini terjadi karena adanya transaction cost didalam mendapatkan dana dari pihak eksternal (Seftianne dan Handayani 2011:42). Dalam pecking order theory juga menjelaskan bahwa perusahaan yang memiliki tingkat keuntungan yang tinggi pada umumnya memiliki utang yang lebih sedikit, hal ini dikarenakan perusahaan tersebut tidak membutuhkan banyak dana dari pihak eksternal. Hal ini berbeda dengan perusahaan yang kurang profitable, karena perusahaan yang kurang profitable tersebut memiliki dana internal yang tidak mencukupi dan utang merupakan sumber eksternal yang paling disukai. Utang lebih disukai karena pertimbangan biaya emisi utang jangka panjang lebih murah dibanding biaya emisi saham. Menurut Siregar (2005) dalam Joni dan Lina (2010, 85-86) ada empat alasan yang mendasari perusahaan lebih mengutamakan utang daripada modal sendiri saat pendanaan eksternal dibutuhkan yaitu:(1) Pasar menderita kerugian karena adanya asimetri informasi antara manajer dengan pasar. Manajemen cenderung tertarik untuk menerbitkan saham baru saat overpriced, sedangkan penerbitan saham baru akan menyebabkan harga saham mengalami penurunan. (2) Utang dan saham sama-sama membutuhkan biaya transaksi bagi perusahaan. Namun, biasanya transaksi utang relatif lebih kecil jika dibandingkan dengan saham. (3) Perusahaan mendapatkan manfaat pajak dengan mengeluarkan sekuritas utang. Manfaat pajak ini diperoleh oleh perusahaan karena adanya biaya bunga yang dapat dibebankan sebagai pengurang penghasilan kena pajak. (4) kontrol manajemen, dalam hal insider ownership, yaitu pemilikan oleh manajemen dapat dipertahankan apabila perusahaan menerbitkan sekuritas utang.

\subsection{Agency Theory}

Agency theory adalah suatu teori yang memprediksi serta menjelaskan suatu tindakan dari agen, dalam hal ini adalah manajer dan pihak yang berkepentingan seperti kreditur atau pemegang 
saham. Teori ini juga mengasumsikan bahwa baik pihak agen maupun maupun pihak yang berkepentingan adalah memaksimalkan atau memperbesar return yang akan diterima dimana ketertarikan atau perhatian tidak terlalu dipermasalahkan dan sebagai hal akhir, hubungan ini akan berdampak pada agency cost (Godfrey et al. 2010, 665). Teori agensi menyatakan bahwa ada konflik kepentingan yang muncul antara pemegang saham (pemilik perusahaan) dengan manajer perusahaan (agen) dimana manajer perusahaan mungkin akan melakukan tindakan atau keputusan yang dapat meningkatkan kesejahteraannya dengan mengorbankan kepentingan pemilik perusahaan. Masalah agensi bukan hanya muncul antara pemegang saham dan manajer tetapi juga dalam hubungannya antara pemegang saham dan pemberi pinjaman. Pemberi pinjaman melakukan pengawasan kepada manajer yang bertindak atas nama pemegang saham untuk mengambil keuntungan dari pemberi pinjaman, biaya pengawasan tersebut disebut biaya agensi (Gitman dan Zutter 2012, 532-533).Biaya yang dikeluarkan oleh prinsipal bertujuan untuk mengawasi kinerja agen yang dalam hal ini adalah manajemen pengelola perusahaan dan untuk meyakinkan bahwa pihak manajemen bertindak secara konsisten sesuai dengan perjanjian dalam kontrak baik antara perusahaan dengan kreditur maupun dengan pemegang saham. Pihak manajemen bertugas untuk menentukan komposisi seimbang antara utang dan ekuitas sehingga total biaya keagenan paling minimal yang harus dikeluarkan.Menurut Joni dan Lina (2010:84), dengan diadakannya pendanaan eksternal yang berupa utang diharapkan biaya yang dikeluarkan oleh pihak pemegang saham sehubungan dengan pengawasan manajemen dapat berkurang karena pihak kreditur yang memberikan pinjaman kepada perusahaan dalam hal ini manajemen sebagai eksekutif organisasi akan melakukan pengawasan guna mendapatkan keyakinan tentang kemampuan perusahaan untuk melunasi kewajibannya. Dengan kata lain, utang mampu memperkecil biaya agensi.

\subsection{Asymmetric information theory}

Asymmetric information theory merupakan suatu kondisi dimana pihak manajemen perusahaan mempunyai lebih banyak informasi dibandingkan dengan pihak lainnya (Seftianne dan Handayani 2011, 42). Di dalam perusahaan, manajer memiliki informasi yang lebih banyak dan lebih akurat dibandingkan dengan pemegang saham dan kreditur. Karena manajer perusahaan memiliki informasi yang lebih banyak, hal ini membuat pihak manajer lebih leluasa dalam mengambil keputusan.Menurut Wimelda dan Marlinah (2013:202), adanya asymmetric information membuat manajer lebih leluasa dalam pengambilan keputusan untuk strategi struktur modal karena manajer menguasai informasi yang ada dalam perusahaan. Informasi baru dalam perusahaan tercermin dalam harga pasar saham dan harus tersedia bagi semua pihak. Ini memungkinkan investor membuat informasi baru direfleksikan dalam harga pasar saham dengan cepat sehingga terjadi pula kompetisi mencari informasi untuk mendapatkan keuntungan sesaat. Dengan demikian pihak manajemen mungkin berfikir bahwa harga saham saat ini sedang overvalue (terlalu mahal). Kalau hal ini yang diperkirakan terjadi, maka manajemen tentu akan berfikir untuk lebih baik menawarkan saham baru (sehingga dapat dijual dengan harga yang lebih mahal dari yang seharusnya).

\subsection{Struktur Modal}

Menurut Setiana dan Rahayu (2012:37), struktur modal adalah hasil atau akibat dari keputusan pendanaan (financing decision) yang intinya memilih antara menggunakan utang atau ekuitas untuk mendanai operasi perusahaan. Sumber pendanaan itu dapat berasal dari sumber internal 
(internal financing) maupun sumber eksternal (external financing). Sumber dana internal dapat berasal dari laba ditahan, sedangkan sumber dana eksternal dapat berasal dari utang (debt financing) dan modal sendiri (equity financing) yang berasal dari penerbitan saham baru. Biaya yang ditimbulkan dari pengadaan utang lebih murah ketimbang dengan penerbitan saham baru. Umumnya perusahaan akan lebih memilih pendanaan yang berasal dari internal. Jika pendanaan internal dirasa kurang barulah dengan pendanaan eksternal.Pendanaan dengan modal sendiri akan menombulkan opportunity cost. Keuntungan dari memiliki saham perusahaan bagi owner adalah kontrol terhadap perusahaan. Namun, return yang dihasilkan dari saham tidak pasti dan pemegang saham adalah pihak pertama yang menanggung risiko perusahaan. Modal sendiri atau ekuitas merupakan modal jangka panjang yang diperoleh dari pihak perusahaan atau pemegang saham. Modal sendiri diharapkan tetap berada dalam perusahaan untuk jangka waktu yang tidak terbatas sedangkan modal pinjaman memiliki jatuh tempo (Setiana dan Rahayu 2012:40).

\section{Pengaruh Likuiditas Terhadap Struktur Modal}

Tingkat likuiditas menggambarkan kemampuan perusahaan untuk membayarkan kewajiban jangka pendeknya dengan menggunakan aktiva lancer yang dimiliki perusahaan. Menurut pecking order theory sebuah perusahaan yang mempunyai likuiditas tinggi akan cenderung tidak menggunakan pembiayaan melalui utang. Hal ini disebabkan karena perusahaan dengan likuiditas tinggi mempunyai dana internal yang besar sehingga perusahaan tersebut akan lebih memilih menggunakan dana internalnya terlebih dahulu untuk membiayai investasinya sebelum menggunakan pembiayaan eksternal melalui utang ataupun dengan menerbitkan saham baru menurut Setiawan (2006) dalam Wimelda dan Marlinah (2013:204). Menurut Seftianne dan Handayani (2011:52), tingkat likuiditas tidak memiliki pengaruh terhadap struktur modal perusahaan. Hal ini dikarenakan makin tinggi kemampuan perusahaan dalam melunasi kewajiban-kewajiban jangka pendeknya maka hal tersebut dapat mengindikasikan perusahaan berada dalam keadaan yang sehat.

\section{Pengaruh Struktur Aktiva Terhadap Struktur Modal}

Struktur aktiva mencerminkan dua komponen aktiva secara garis besar dalam komposisinya yaitu terdiri dari aktiva lancer dan aktiva tetap. Aktiva lancer adalah uang kas dan aktiva-aktiva lain yang dapat direalisasikan menjadi uang kas atau dijual atau dikonsumsi dalam suatu periode akuntansi. Sedangkan aktiva tetap adalah berwujud yang diperoleh dalam bentuk siap pakai atau dibangun lebih dahulu yang digunakan dalam operasi perusahaan, tidak dimasukkan untuk dijual dalam rangka kegiatan normal perusahaan (Seftianne dan Handayani 2011:47).Tangibilitas merupakan variabel yang penting dalam keputusan pendanaan perusahaan, karena aktiva juga dapat menyediakan jaminan bagi pihak kreditur. Struktur aktiva juga dapat memengaruhi fleksibilitas perusahaan dalam menentukan alternatif pendanaan eksternal karena dianggap memiliki tingkat risiko kebangkrutan yang relative lebih rendah daripada perusahaan dengan rasio aktiva tetap yang rendah (Joni dan Lina 2010:87). Aktiva yang berwujud (tangible) akan mudah dijadikan sebagai jaminan sehingga akan menurunkan risiko pemberi pinjaman. Makin tinggi nilai aktiva pada neraca, maka akan makin besar pula kesediaan pemberi pinjaman untuk memberikan pinjaman. Dengan demikian akan menyebabkan debt makin besar. 


\subsection{Penelitian Terdahulu}

Penelitian yang dilakukan oleh Sheikh dan Wang (2011:117) menunjukkan pengaruh negatif antara likuiditas dengan struktur modal. Hal ini dikarenakan perusahaan dengan tingkat likuiditas tinggi mampu untuk membiayai kegiatan operasionalnya tanpa dengan cara berutang.Penelitian yang dilakukan oleh Umer (2014:60) menunjukkan bahwa likuiditas berpengaruh positif terhadap struktur modal. Hal ini menunjukkan bahwa perusahaan dengan tingkat likuiditas tinggi berarti perusahaan mampu untuk membayar kewajiban jangka pendeknya, dengan demikian perusahaan memilih berutang. Hasil penelitian ini berbeda dengan penelitian yang dilakukan oleh Seftianne dan Handayani (2011:51) dan Wimelda dan Marlinah (2013:210) yang tidak menunjukkan adanya pengaruh dari likuiditas terhadap struktur modal.

\subsubsection{Struktur Aktiva dan struktur Modal}

Peneliatia yang dilakukan oleh Sheikh dan Wang (2011:117) menunjukkan pengaruh negative antara struktur aktiva dengan struktur modal. Hasil penelitian Sheikh dan Wang (2011:117) sejalan dengan penelitian yang dilakukan Alzomaia (2014:53). Hasil penelitian tersebut mendukung pecking order theory yang menyatakan bahwa perusahaan dengan tangibilitas yang tinggi dapat memperoleh pedanaan ekuitas dengan biaya lebih rendah, sehingga perusahaan lebih memilih pendanaan ekuitas, hal tersebut juga dikarenakan asymmetry information yang lebih rendah. Penelitian yang dilakukan oleh Umer (2014:60) menunjukkan adanya pengaruh positif terhadap struktur modal. Hal ini disebabkan oleh makin banyak aset berwujud yang dimiliki oleh suatu perusahaan untuk dijadikan jaminan, makin mudah bagi perusahaan tersebut untuk memperoleh pembiayaan utang karena kreditur lebih yakin dalam memberikan pinjaman. Hasil penelitian Umer (2014:60) sejalan dengan penelitian yang dilakukan oleh Kiran (2013:43) dan Joni dan Lina (2010:93). Namun penelitian yanag dilakukan oleh Seftianne dan Handayani (2011: 51) tidak membuktikan adanya pengaruh dari tangibilitas terhadap struktur modal.

\subsection{Kerangka Pikir}

Berdasarkan tujuan penelitian yang telah diuraikan, kerangka pikir atau model penelitian yang dikembangkan dalam penelitian ini adalah:

\section{Gambar 2.1 \\ Kerangka Pikir}

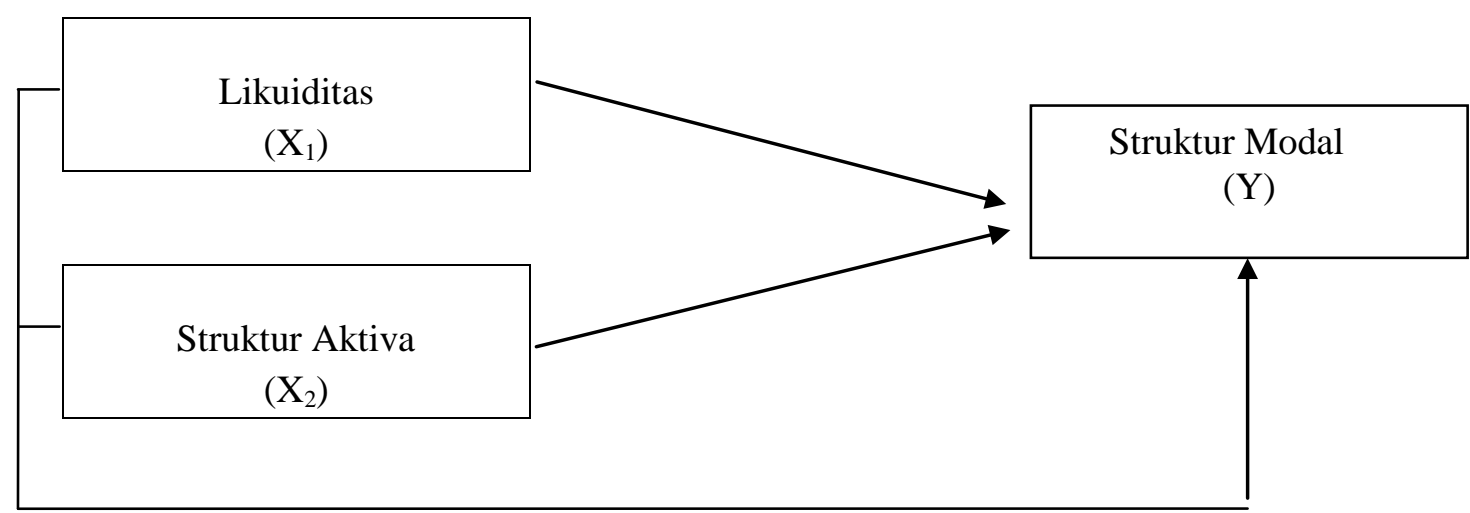

Sumber: Penulis 2017 


\section{METODOLOGI PENELITIAN}

\subsection{Bentuk Penelitian}

Bentuk penelitian yang digunakan dalam penelitian ini adalah causal effect atau kausalitas. Variabel terikat yang digunakan dalam penelitian ini adalah struktur modal, sedangkan variabel bebas yang digunakan dalam penelitian ini adalah likuiditas dan struktur aktiva.

\subsection{Definisi Operasional Variabel dan Pengukurannya}

\subsubsection{Variabel terikat}

Variabel terikat adalah variabel yang menjadi perhatian utama dalam penelitian (Sekaran dan Bougie 2013:69). Variabel terikat juga merupakan variabel yang tidak bebas atau terikat dimana variabel ini dipengaruhi oleh variabel-variabel bebas. Variabel terikat yang digunakan dalam penelitian ini adalah struktur modal. Struktur modal adalah kombinasi antara utang jangka panjang dan ekuitas yang dikelola oleh perusahaan (Gitman dan Zutter 2012:508). Struktur modal menggunakan skala rasio, berdasarkan debt ratio yang dapat diukur dengan rumus (Sheikh dan Wang 2011:124):

$$
\text { Debt Ratio }=\frac{\text { Total Utang }}{\text { Total Aset }}
$$

\subsubsection{Variabel Bebas}

Variabel independen adalah variabel yang memengaruhi variabel terikat, baik secara positif dan negatif (Sekaran dan Bougie 2013,:70). Variabel ini tidak dipengaruhi oleh variabel lainnya atau variabel yang memengaruhi penyebab berubahnya variasi terikat. Di dalam penelitian ini menggunakan variabel bebas yang terdiri dari likuiditas dan struktur aktiva.

\section{Likuiditas}

Tingkat likuiditas merupakan tingkat kemampuan perusahaan dalam memenuhi kewajiban jangka pendeknya dengan aktiva lancar yang dimilikinya (Seftianne dan Handayani 2011:49). Likuiditas dapat diukur dengan skala rasio dan diukur dengan menggunakan rumus (Sheikh and Wang 2011: 124) :

$$
\text { Likuiditas }=\frac{\text { Aset Lancar }}{\text { Utang Lancar }}
$$

\section{Struktur Aktiva}

Menurut Wimelda dan Marlinah (2013:209), struktur aktiva menggambarkan sebagian aset yang dimiliki perusahaan yang dapat dijadikan aset kolateral (jaminan) untuk mendapatkan pendanaan eksternal. Struktur aktiva dapat dihitung dengan skala rasio yang menggunakan rumus (Sheikh and Wang 2011:124) :

Aset Tetap Bersih

$$
\text { Struktur Aktiva }=\cdot \frac{}{\text { Total Aset }}
$$




\subsection{Metode Analisis Data}

\subsection{1. $\quad$ Uji Statistik Deskriptif}

Menurut Ghozali (2013, 19), statistik deskriptif dapat memberikan gambaran (deskriptif) suatu data yaitu dapat dilihat dari nilai rata-rata, nilai tengah, deviasi standar, nilai maksimum, nilai minimum, sum, range, kurtosis, dan skewness (kemencengan).

\subsubsection{Uji Kualitas Data}

\section{Uji Normalitas Data Residual}

Cara yang dapat digunakan untuk menguji normalitas adalah dengan melalui pengamatan residual. Apabila data bersifat normal, maka data residual akan terdistribusi normal dan bebas, yaitu perbedaan antara nilai prediksi dengan skor yang sesungguhnya, atau error akan terdistribusi secara simetris di sekitar nilai rata-rata (Ghozali 2013, 29-30).Uji statistik adalah tingkat kemencengan dan keruncingan data dan menganalisis dengan menggunakan uji KolmogrovSmirnov dengan tingkat $\alpha=0,05$ dengan kriteria pengujian sebagai berikut (Ghozali 2013:32):

1. Jika nilai Asymp. Sig. (2-tailed) $<0,05$, berarti data residual tidak berdistribusi normal.

2. Jika nilai Asymp. Sig. (2-tailed) $\geq 0,05$, berarti data residual berdistribusi normal.

\section{Uji Outlier}

Apabila setelah dilakukan pengujian ternyata diperoleh hasil tidak terdistribusi normal, hal ini menunjukan bahwa data yang dipakai tidak valid. Jika terjadi hal tersebut, maka uji outlier dapat diterapkan dalam penelitian ini. Deteksi terhadap outlier dapat dilakukan dengan menentukan nilai batas yang akan dikategorikan sebagai data outlier yaitu dengan mengkonversikan nilai data ke dalam standardized score (Z-score) yang memiliki nilai rata-rata sama dengan nol dan standar deviasi sama dengan satu. Menurut Hair (1998) dalam Ghozali (2013:41) untuk kasus sampel kecil (kurang dari 80), maka standar skor dengan nilai $\geq 2,5$ dinyatakan Outlier. Untuk sampel besar standar skor dinyatakan outlier jika nilainya pada kisaran 3 sampai 4. Jika standar skor tidak digunakan, maka kita dapat menentukan data outlier jika data tersebut nilainya lebih besar dari 2,5 standar deviasi atau 3 sampai 4 standar deviasi tergantung dari besarnya sampel.

\subsubsection{Uji Asumsi Klasik}

\section{Uji Autokorelasi}

Uji autokorelasi digunakan untuk menguji apakah dalam model regresi linier ada korelasi antara kesalahan pengganggu pada periode $t$ dengan kesalahan pengganggu pada periode $t-I$ (sebelumnya). Suatu data yang baik adalah data yang bebas dari masalah autokorelasi di dalamnya (Ghozali 2013:110). Pengujian autokorelasi dapat menggunakan Uji BrueschGodfrey.Ketentuan yang digunakan untuk mendeteksi ada atau tidaknya autokorelasi yaitu (Ghozali 2013:118):

1. Apabila nilai koefisien parameter untuk residual lag 2 (res_2) $<0,05$ maka terdapat autokorelasi sehingga data tidak baik digunakan.

2. Apabila nilai koefisien parameter untuk residual lag 2 (res_2) $\geq 0,05$ maka tidak terdapat autokorelasi sehingga data baik digunakan. 


\section{Uji Multikolinearitas}

Uji multikolinearitas digunakan untuk menguji apakah dalam model regresi ditemukan adanya korelasi antar variabel bebas. Di dalam model regresi yang baik seharusnya tidak terjadi korelasi antara variabel bebas

atau tidak (Ghozali 2013:105). Untuk mendeteksi keberadaan multikolinearitas, dapat dilihat dari nilai Tolerance dan Variance Insflation Factor (VIF), dengan kriteria pengambilan keputusan sebagai berikut (Hair et al. 2010, 204):

1. Jika Tolerance $\leq 0,1$ dan $V I F \geq 10$ maka dapat disimpulkan bahwa terdapat multikolinearitas.

2. Jika Tolerance $>0,1$ dan VIF $<10$ maka dapat disimpulkan bahwa tidak terdapat multikolinearitas.

\section{Uji Heteroskedastisitas}

Uji heteroskedastisitas digunakan untuk menguji apakah dalam sebuah model regresi terjadi ketidaksamaan variance dari residual satu pengamatan ke pengamatan lain. Suatu model regresi yang baik adalah tidak memiliki masalah heteroskedastisitas atau disebut juga dengan homokedastisitas (Ghozali 2013, 139). Uji heteroskedastisitas dapat dilakukan dengan cara grafik dan non grafik.Untuk mendeteksi ada atau tidaknya heteroskedastisitas adalah dengan melakukan uji Glejser yaitu dengan cara meregresi nilai absolut terhadap variabel bebas (Ghozali 2013, 142). Kriteria untuk menentukan terjadinya heteroskedastisitas adalah sebagai berikut:

1. Jika nilai signifikansinya $<0,05$ hal berarti terjadi heteroskedastisitas.

2. Jika nilai signifikansinya $\geq$ dari 0,05 hal ini berarti tidak terjadi heteroskedastisitas.

\subsubsection{Uji Hipotesis}

Uji ini digunakan untuk menganalisis variabel-variabel mempengaruhi struktur modal, yaitu pengaruh likuiditas dan struktur aktiva terhadap struktur modal. Metode analisis data yang digunakan adalah analisa regresi berganda (Multiple regression analysis) dengan alpha 5\%. Model penelitian dengan persamaan regresi dalam penelitian ini dapat dirumuskan sebagai berikut:

$\mathrm{DR}=\boldsymbol{\beta}_{0}+\boldsymbol{\beta}_{1}$ Lik $+\boldsymbol{\beta}_{2} \mathrm{SA}+{ }_{\mathrm{e}}$

Keterangan:

$\begin{array}{ll}\text { DR } & \text { Struktur Modal } \\ \beta_{0} & \text { Konstanta Tetap } \\ \beta_{1, \beta 2} & \text { Koefisien Regresi } \\ \text { Lik } & \text { Likuiditas } \\ \text { SA } & \text { Struktur Aktiva } \\ \text { e } & \text { error }\end{array}$

\section{Analisis Koefisien Korelasi (Uji R)}

Koefisien korelasi adalah koefisien yang mengindikasikan adanya kekuatan hubungan antara dua variabel. Tanda positif atau negatif menunjukan arah dari hubungan. Analisis korelasi dilakukan untuk melihat keeratan hubungan antara dua variabel yang diamati. Pada kasus ini peneliti ingin 
mengetahui keeratan hubungan antara Likuiditas $\left(\mathrm{X}_{1}\right)$ dan Struktur Aktiva $\left(\mathrm{X}_{2}\right)$ terhadap Struktur Modal (Y). Analisis korelasi dalam penelitian ini menggunakan persamaan korelasi Pearson Product Moment (PPM). Nilai koefisien korelasi berkisar antara +1 sampai dengan -1 , dengan +1 berarti hubungan positif sempurna, 0 mengindikasikan tidak adanya hubungan, dan -1 menandakan hubungan negatif sempurna (Hair et al. 2010, 156-157). Menurut Santoso (2014:152), pengelompokan kuat lemahnya korelasi adalah sebagai berikut:

1. $\mathrm{R}<0,5$ berarti korelasi lemah.

2. $\mathrm{R} \geq 0,5$ berarti korelasi kuat.

\section{Analisis Adjusted R-Square (Koefisien Determinasi)}

Menurut Ghozali (2013, 97), Uji adjusted R-Square digunakan untuk mengukur seberapa besar kemampuan variabel independen dalam menerangkan variasi variabel dependen. Nilai koefisien determinasi adalah antara nol dan satu. Jika nilai koefisien korelasi mendekati satu berarti variabel-variabel independen memberikan hampir semua imformasi yang dibutuhkan untuk memprediksi variabel dependen, sedangkan nilai koefisien yang kecil mengindikasikan kemampuan yang amat terbatas dari variabel-variabel independen dalam menjelaskan variabel dependen. Koefisien determinasi juga menyatakan besar kecilnya kontribusi variabel bebas terhadap variabel terikat. Dengan demikian bisa diketahui seberapa besar variabel bebas mempengaruhi variabel terikat atau mengukur besarnya persentase dari variabel bebas terhadap variabel terikat. Karena dalam proses analisa data ini penulis menggunakan software SPSS Versi 23 for Windows, maka koefisien determinasi dilambangkan dengan R Square.

\section{Uji Signifikansi Simultan (Uji Statistik F)}

Uji $\mathrm{F}$ adalah pengujian untuk menunjukkan apakah suatu model fit atau tidak untuk dilakukan penelitian (Hair et al. 2010, 209). Ketentuan yang digunakan dalam pengambilan keputusan adalah (Santoso 2014, 152):

1. Jika nilai signifikansi $<0,05$ berarti model regresi fit dan data yang digunakan sesuai dengan model.

2. Jika nilai signifikansi $\geq 0,05$ berarti model regresi tidak fit dan data yang digunakan tidak sesuai dengan model.

\section{Uji Signifikansi Parameter Individual (Uji Statistik t)}

Uji t digunakan untuk mengetahui seberapa jauh suatu variabel independen secara individual dalam menerangkan variasi variabel terikat (Ghozali 2013, 98). Di dalam penelitian ini tingkat $\alpha$ yang digunakan adalah 5\% dengan tingkat keyakinan 95\%. Kriteria yang digunakan untuk uji t adalah:

1. Jika nilai probabilitas signifikansi $<0,05$ maka hipotesis alternatif diterima, artinya suatu variabel bebas merupakan penjelas yang signifikan terhadap variabel terikat.

2. Jika nilai probabilitas signifikansi $\geq 0,05$ maka hipotesis alternative tidak diterima, artinya suatu variabel bebas bukan merupakan penjelas yang signifikan terhadap variabel terikat secara individual terhadap variabel terikat. 


\section{ANALISIS DAN PEMBAHASAN}

\subsection{Statistik Deskriptif}

Statistik deskriptif menunjukan nilai rata-rata, standar deviasi, maksimum dan minimum untuk masing-masing variabel penelitian. Hasil pengolahan uji statistik deskriptif adalah sebagai berikut:

Tabel 4.1

\section{Hasil Uji Statistik Deskriptif}

Descriptive Statistics

\begin{tabular}{|l|r|r|r|r|r|}
\hline & \multicolumn{1}{|c|}{$\mathrm{N}$} & \multicolumn{1}{c|}{ Minimum } & \multicolumn{1}{c|}{ Maximum } & \multicolumn{1}{c|}{ Mean } & Std. Deviation \\
\hline Likuiditas & 165 & .00264 & 10.59998 & 1.5962852 & 1.88064553 \\
Struktur Aktiva & 165 & -113.71691 & 8.77507 & -.1553590 & 8.96295124 \\
Debt Ratio & 165 & .105900 & .763920 & .38535188 & .166425206 \\
Valid N (listwise) & 165 & & & & \\
\hline
\end{tabular}

Sumber: Output Data SPSS 23

Tabel 4.1 menunjukan bahwa jumlah data yang diteliti adalah sebanyak 165 data. Nilai mean menunjukkan nilai rata-rata hitung dari seluruh sampel penelitian. Nilai Standard Deviation atau standar deviasi menunjukkan besarnya simpangan dari observasi terhadap nilai rata-rata (mean). Nilai minimum menunjukkan nilai terendah dari seluruh sampel penelitian dan nilai maximum menunjukkan nilai tertinggi dari seluruh sampel penelitian.Variabel struktur modal (DR) mempunyai nilai minimum sebesar 0,105900 , nilai tertinggi sebesar 0,763920 , nilai rata-rata sebesar 0,38535188 dan standar deviasi sebesar 0,166425206. Variabel Struktur Aktiva (SA) mempunyai nilai terendah sebesar $-113,71691$, nilai tertinggi sebesar 8,77507, nilai rata-rata sebesar -0,1553590 dan standar deviasi sebesar 8,96295124.Variabel Likuiditas (LIK) mempunyai nilai terendah sebesar 0,00264, nilai tertinggi sebesar 10,59998, nilai rata-rata sebesar 1,5962852 dan standar deviasi sebesar 1,88064553.

\subsection{Uji Normalitas Residual}

Uji normalitas residual digunakan untuk menentukan apakah data terdistribusi normal atau tidak pengujian normalitas residual dalam penelitian ini menggunakan uji kolmogorov-smirnov. Hasil pengujian normalitas residual sebelum uji outlier dapat dilihat pada tabel 4.2 berikut ini:

Tabel 4.2

Hasil Uji Normalitas Residual Sebelum UJi Outlier

One-Sample Kolmogorow-Smirnov Test

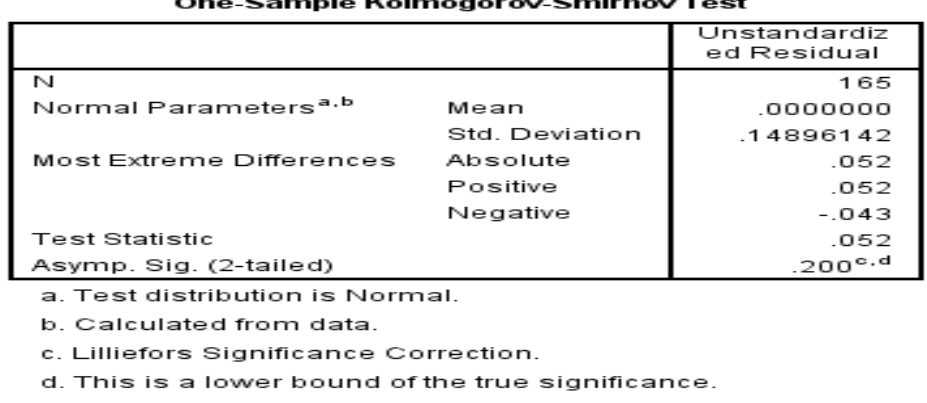

Sumber: Hasil Pengolahan Data SPSS 23 
Berdasarkan tabel 4.2, hasil uji normalitas residual dengan menggunakan One-Sample Kolmogorov-Smirnov Test dapat disimpulkan bahwa nilai residu dari variabel Struktur Modal (Debt Ratio) (DR), Struktur Aktiva (SA), Likuiditas (LIk), mempunyai asymp. Sig (2-tailed) sebesar 0,001 lebih kecil dari nilai alpha 0,05 sehingga data tidak berdistribusi normal. Olek karena itu, dilakukan uji outlier untuk mengurangi data yang bersifat ekstrim atau menyimpan agar data menjadi berdistribusi normal. Data yang digunakan memiliki z-score antar 3 dan -3, apabila diatas atau dibawah batas tersebut harus dihilangkan dari penelitian. Setelah dilakukan outlier terdapat satu data yang harus dihilangkan sehingga data yang digunakan sebanyak 165 sampel. Hasil pengujian normalitas residual setelah uji outlier dapat dilihat pada tabel 4.3 berikut ini:

Tabel 4.3

Hasil Uji Normalitas Residual setelah outlier

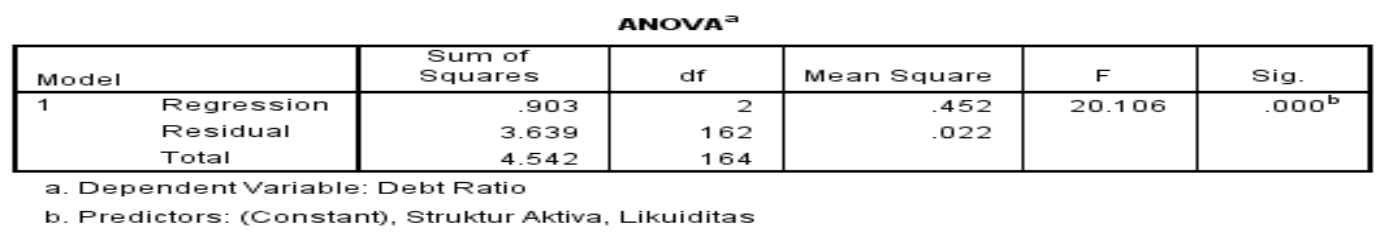

Sumber : Hasil Pengolahan Data SPSS 23

Setelah dilakukan uji outlier maka dapat dilihat pada tabel 4.3 bahwa nilai residu dari variabel Struktur Modal (DR), Struktur Aktiva (SA), Likuiditas (LIK), mempunyai asymp. Sig (2-tailed) sebesar 0,00 lebih kecil dari nilai alpha 0,05 maka dapat disimpulkan bahwa data berdistribusi secara tidak normal. Oleh karena itu, data yang digunakan adalah data sesudah uji outlier dengan jumlah sampel yang digunakan sebanyak 165 sampel.

\subsection{Uji Asumsi Klasik}

\subsubsection{Uji Autokorelasi}

Hasil dari pengujian autokorelasi dapat dilihat pada tabel 4.4 dibawah ini:

Tabel 4.4.

Hasil Uji Autokorelasi

\begin{tabular}{cr}
\hline Variabel & sig. \\
\hline RES_2 & 0,293 \\
\hline
\end{tabular}

Sumber: Hasil Pengolahan Data SPSS 23

Berdasarkan tabel 4.4 dengan, menggunakan alat uji Bruesch-Godfrey, maka dapat disimpulkan bahwa hasil uji autokorelasi, nilai signifikansi dari RES_2 sebesar 0,293 lebih besar dari alpha 0,05 . Hasil ini berarti tidak terjadi autokorelasi sehingga data baik digunakan dalam model regresi. 


\subsubsection{Uji Multikolionearitas}

Hasil pengujian multikolioearitas dapat dilihat pada tabel 4.5. berikut ini:

Tabel 4.5.

Hasil Uji Multikolionearitas

\begin{tabular}{|c|c|c|c|c|c|c|c|c|}
\hline \multicolumn{9}{|c|}{ Coefficients $^{a}$} \\
\hline \multirow{2}{*}{\multicolumn{2}{|c|}{ Model }} & \multicolumn{2}{|c|}{ Unstandardized Coefficients } & \multirow{2}{*}{ 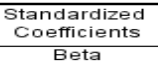 } & \multirow[b]{2}{*}{$t$} & \multirow[b]{2}{*}{ Sig. } & \multicolumn{2}{|c|}{ Collinearity Statistics } \\
\hline & & B & Std. Error & & & & Tolerance & VIF \\
\hline 1 & $\begin{array}{l}\text { (Constant) } \\
\text { Likuiditas } \\
\text { Struktur Aktiva }\end{array}$ & $\begin{array}{r}.448 \\
-.039 \\
-.001\end{array}$ & $\begin{array}{l}.015 \\
.006\end{array}$ & $\begin{array}{r}-.444 \\
-.030\end{array}$ & $\begin{array}{l}29.216 \\
-6.309\end{array}$ & $\begin{array}{l}.000 \\
.000 \\
672\end{array}$ & .999 & 1.001 \\
\hline
\end{tabular}

Sumber: Hasil Pengolahan Data SPSS 23

Berdasarkan hasil iji multikolionearitas pada tabel 4.5, dapat disimpulkan bahwa model regresi yang ada tidak terdapat multikolionearitas karena variabel Struktur Aktiva (SA), Likuiditas (LIK), mempunyai nilai tolerance di atas 0,1 dan nilai Variance Inflation Factor (VIF) kurang dari 10. Hal ini berarti tidak terjadi multikolionearitas antar variabel terikat.

\subsubsection{Hasil Heteroskedastisitas}

Hasil pengujian heteroskedastisitas dapat dilihat pada tabel 4.6. berikut ini:

Tabel 4.6

Hasil Uji Heteroskedastisitas

\begin{tabular}{|c|c|c|}
\hline Varabel & Sig & Kesimpulan \\
\hline SA & 0,72 & Tidak terjadi heteroskedastisitas \\
\hline LIK & 0,00 & Tidak terjadi heteroskedastisitas \\
\hline
\end{tabular}

Sumber: Hasil Pengolahan Data SPSS 23

Berdasarkan hasil uji heteroskedastisitas pada table 4.6, dengan menggunakan alat uji Glejser, menunjukan bahwa variabel Struktur Aktiva (SA), angka signifikansinya lebih besar dari alpha 0,05 maka tidak terjadi heteroskedastisitas. Sedangkan variabel Likuiditas (LIK) angka signifikansinya lebih kecil dari 0,05 maka terjadi heteroskedastisitas yang berarti adanya ketidaksamaan variance dari residual satu pengamatan ke pengamatan lain atau dapat dikatakan terjadi heteroskedastisitas.

\subsection{Uji Hipotesis}

\subsubsection{Uji Koefisien Korelasi (R)}

Hasil pengujian koefisien korelasi (R) dapat dilihat dari tabel 4.7 berikut ini: 
Tabel 4.7.

Hasil Uji Koefisien Korelasi (R)

\begin{tabular}{|c|c|c|c|c|c|}
\hline \multicolumn{6}{|c|}{ Model Summary } \\
\hline Model & $\mathrm{R}$ & R Square & $\begin{array}{l}\text { Adjusted R } \\
\text { Square }\end{array}$ & $\begin{array}{l}\text { Std. Error of } \\
\text { the Estimate }\end{array}$ & $\begin{array}{l}\text { Durbin- } \\
\text { Watson }\end{array}$ \\
\hline 1 & $.446^{a}$ & .199 & .189 & .149878115 & 1.871 \\
\hline
\end{tabular}

a. Predictors: (Constant), Struktur Aktiva, Likuiditas

b. Dependent Variable: Debt Ratio

Sumber: Hasil Pengolahan Data SPSS 23

Berdasarkan tabel 4.7 nilai koefisien korelasi (R) sebesar 0,446, nilai ini berada pada interval 0.40 - 0.599 pada tabel interpretasi koefisien korelasi yang berarti terdapat hubungan positif yang cukup kuat antara likuiditas dan struktur aktiva terhadap struktur modal. Apabila nilai koefisien korelasi ini dikonsultasikan menurut Santoso (2014:152), nilai koefisien korelasi ® lebih kecil dari 0,5 maka dapat disimpulkan bahwa hubungan antara variabel terikat (struktur modal) dengan variabel bebas (struktur aktiva dan likuiditas) adalah lemah.

\subsubsection{Uji Koefisien Determinasi (Adjusted $R$-Square)}

Hasil pengujian Koefisien Determinasi ( Adjusted R-Square ) dapat dilihat dari tabel 4.8 berikut ini :

\section{Tabel 4.8}

Hasil Uji Koefisien Determinasi ( Adjusted R-Square )

\begin{tabular}{|l|l|r|r|c|c|}
\hline \multicolumn{1}{|c|}{ Model Summary } \\
\hline Model & R & R Square & $\begin{array}{c}\text { Adjusted R } \\
\text { Square }\end{array}$ & $\begin{array}{c}\text { Std. Error of } \\
\text { the Estimate }\end{array}$ & $\begin{array}{c}\text { Durbin- } \\
\text { Watson }\end{array}$ \\
\hline 1 & $.446^{\mathrm{a}}$ & .199 & .189 & .149878115 & 1.871 \\
\hline
\end{tabular}

a. Predictors: (Constant), Struktur Aktiva, Likuiditas

b. Dependent Variable: Debt Ratio

Sumber: Hasil Pengolahan Data SPSS 23

Berdasarkan tabel 4.8. diatas, nilai koefisien korelasi jauh mendekati satu berarti nilai koefisien ini kecil dan mengindikasikan kemampuan yang terbatas dari variabel-variabel bebas dalam menjelaskan variable terikat. Berdasarkan tabel 4.8 diatas juga diperoleh nilai koefisien determinan (adjust R-Square) menunjukkan nilai 0,199 yang berarti besarnya variasi variabel terikat (struktur modal) yang dapat dijelaskan oleh variable bebas (struktur aktiva dan likuiditas) sebesar 19.9\% sedangkan sisanya sebesar $\mathbf{8 0 . 1 \%}$ dapat dijelaskan oleh faktor-faktor lain yang tidak terdapat dalam model penelitian. 


\subsubsection{Uji F}

Hasil Uji Statistik F dapat dilihat pada tabel 4.9 berikut ini:

Tabel 4.9

Hasil Uji F

ANOVA ${ }^{a}$

\begin{tabular}{|ll|r|r|r|r|c|}
\hline Model & & $\begin{array}{c}\text { Sum of } \\
\text { Squares }\end{array}$ & df & Mean Square & F & Sig. \\
\hline 1 & Regression & .903 & 2 & .452 & 20.106 & $.000^{\mathrm{b}}$ \\
& Residual & 3.639 & 162 & .022 & & \\
& Total & 4.542 & 164 & & & \\
\hline
\end{tabular}

a. Dependent Variable: Debt Ratio

b. Predictors: (Constant), Struktur Aktiva, Likuiditas

Sumber: Hasil Pengolahan Data SPSS 23

Hasil dari pengujian uji $\mathrm{F}$ pada tabel 4.9 diperoleh nilai signifikansi sebesar 0,000. Nilai signifikansi lebih kecil dari alpha sebesar 0,05 yang berarti model fit. Hal ini menunjukkan data layak digunakan dalam model penelitian. Uji F digunakan untuk menguji apakah secara bersamasama seluruh variabel bebas mempunyai pengaruh yang signifikan terhadap variabel terikat. Berdasarkan hasil analisis tersebut diperoleh nilai $p$-value 0.000 sehingga nilai ini lebih kecil dari nilai $\alpha(0,05)$ atau $p$-value $<\alpha(0,05)$, maka $\mathrm{Ha}_{3}$ yang menyatakan likuiditas dan struktur aktiva secara bersama - sama berpengaruh signifikan terhadap struktur modal diterima atau terbukti. Jadi variabel likuiditas dan struktur aktiva secara bersama-sama (simultan) memiliki pengaruh signifikan terhadap struktur modal. Jika penentuan keputusannya dengan cara membandingkan $F_{\text {hitung }}$ dengan $F_{\text {tabel}}$, maka dasar pengambilan keputusannya adalah $F_{\text {hitung }}>F_{\text {tabel }}(20.106>3.05), H_{3}$ diterima yaitu variabel likuiditas dan struktur aktiva secara bersama-sama (simultan) memiliki pengaruh signifikan terhadap struktur modal.

\subsubsection{Analisis Regresi Berganda Dan Uji Statistik t}

Analisis regresi adalah analisis untuk mengetahui seberapa besar suatu variabel berpengaruh pada variabel lainnya. Dalam hal ini kita akan melihat berapa besar pengaruh perubahan variabel likuiditas dan struktur modal terhadap perubahan variabel struktur modal. Selain itu persamaan regresi juga dapat digunakan sebagai alat untuk memprediksi (forecasting) hasil penilaian di tahun-tahun berikutnya.

Tabel 4.10

Hasil Uji t

\begin{tabular}{|c|c|c|c|c|c|c|c|c|}
\hline \multicolumn{9}{|c|}{ Coefficients $^{a}$} \\
\hline \multirow{2}{*}{\multicolumn{2}{|c|}{ Model }} & \multicolumn{2}{|c|}{ Unstandardized Coefficients } & \multirow{2}{*}{$\begin{array}{c}\begin{array}{c}\text { Standardized } \\
\text { Coefficients }\end{array} \\
\text { Beta } \\
\end{array}$} & \multirow[b]{2}{*}{$t$} & \multirow[b]{2}{*}{ Sig. } & \multicolumn{2}{|c|}{ Collinearity Statistics } \\
\hline & & $B$ & Std. Error & & & & Tolerance & VIF \\
\hline \multirow[t]{3}{*}{1} & (Constant) & .448 & .015 & & 29.216 & .000 & & \\
\hline & Likuiditas & -.039 & .006 & -.444 & -6.309 & .000 & .999 & 1.001 \\
\hline & Struktur Aktiva & -.001 & .001 & -.030 & -.424 & .672 & .999 & 1.001 \\
\hline
\end{tabular}

a. Dependent Variable: Debt Ratio

Sumbe: Hasil Pengolahan Data SPSS 
Berdasarkan tabel tersebut maka persamaan regresi yang digunakan dalam penelitian ini adalah sebagai berikut:

$$
\begin{aligned}
& \mathrm{Y}=0,448-0,444 \mathrm{X}_{1}-0,030 \mathrm{X}_{2}+\mathrm{e} \text { atau } \\
& \mathrm{DR}=0,448-0,444 \text { Lik }^{-0,030 S A}+\mathrm{e}
\end{aligned}
$$

Nilai konstanta menunjukkan angka 0,448 yang berarti bila semua variabel bebas bernilai nol, maka struktur modal akan bernilai 0,448. Selain itu berdasarkan persamaan régressif $\mathbf{Y}=\mathbf{0 , 4 4 8}$

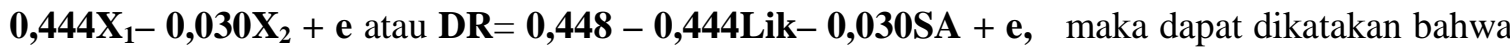
Likuiditas $\left(\mathrm{X}_{1}\right)$ dan struktur aktiva $\left(\mathrm{X}_{2}\right)$ terdapat pengaruh yang signifikan terhadap struktur modal ( $\mathrm{Y}$ ) dengan proporsi sebesar $-0,444$ satuan dan -0,030 satuan. Hal ini berarti jika nilai $\mathrm{X}_{1}$ dan $\mathrm{X}_{2}$ mengalami kenaikan atau penurunan sebesar satu satuan, maka menyebabkan nilai $\mathrm{Y}$ meningkat atau menurun juga sebesar $-0,444$ satuan dan $-0,030$ satuan. Uji-t digunakan untuk mengetahui seberapa jauh suatu variabel bebas secara individual dalam menerangkan variasi variabel terikat (Ghozali 2013,98). Dalam penelitian ini tingkat $\alpha$ yang digunakan adalah 5\% dengan tingkat keyakinan 95\%, hasil penelitian seperti terlihat pada tabel 4.10 diketahui nilai tsign variabel likuiditas 0.000 artinya lebih kecil dari nilai $\alpha 0,05(0,000<0,05)$ maka hipotesis $\mathrm{Ha}_{1}$ diterima, artinya suatu variabel likuiditas merupakan penjelas yang signifikan terhadap variabel struktur modal secara individual atau parsial. Sedangkan nilai t-sign variabel struktur aktiva 0.672 artinya lebih besar dari 0,05 $(0,672>0,05)$ maka hipotesis $\mathrm{H}_{\mathrm{a} 2}$ ditolak artinya variabel struktur aktiva bukan merupakan penjelas yang signifikan terhadap variabel struktur modal secara individual.

\section{SIMPULAN DAN SARAN}

\subsection{Simpulan}

Setelah melakukan analisis dan pembahasan dengan sampel penelitian perusahaan non keuangan yang terdaftar secara konsisten di Bursa Efek Indonesia selama tahun 2009 sampai dengan tahun 2013, maka kesimpulan yang diperoleh adalah:

1. Nilai t-sign variabel likuiditas 0.000 artinya lebih kecil dari nilai $\alpha 0,05(0,000<0,05)$ maka hipotesis $\mathrm{Ha}_{1}$ diterima, artinya suatu variabel likuiditas merupakan penjelas yang signifikan terhadap variabel struktur modal secara individual atau parsial. Ini berarti likuiditas berpengaruh terhadap struktur modal. Hasil penelitian ini konsisten dengan penelitian sheikh dan Wang (2011), dan Umer (2014). Namun hasil penelitian ini tidak konsisten dengan penelitian yang dilakukan Seftianne dan Handayani (2011), dan Wimelda dan Marlinah (2013) yang menyatakan likuiditas tidak berpengaruh terhadap struktur modal.

2. Nilai t-sign variabel struktur aktiva 0.672 artinya lebih besar dari $0,05(0,672>0,05)$ maka hipotesis $\mathrm{H}_{\mathrm{a} 2}$ ditolak artinya variabel struktur aktiva bukan merupakan penjelas yang signifikan terhadap variabel struktur modal secara individual. Ini berarti struktur aktiva tidak berpengaruh terhadap struktur modal. Hasil penelitian ini tidak konsisten dengan penelitian Wimelda dan Marlinah (2013), Joni dan Lina (2010), Umer (2014), Sheikh dan Wang (2011), dan Alzomaia (2014). Namun hasil penelitian ini konsisten dengan penelitian yang dilakukan oleh Seftianne dan Handayani (2010) menyatakan struktur aktiva berpengaruh terhadap struktur modal.

3. Hasil dari pengujian uji $\mathrm{F}$ pada tabel 4.9 diperoleh nilai signifikansi sebesar 0,000. Nilai signifikansi lebih kecil dari alpha sebesar 0,05 yang berarti model fit. Hal ini menunjukkan data layak digunakan dalam model penelitian. Berdasarkan hasil analisis tersebut diperoleh 
nilai $p$-value 0.000 sehingga nilai ini lebih kecil dari nilai $\alpha(0,05)$ atau $p$-value $<\alpha(0,05)$, maka $\mathrm{Ha}_{3}$ yang menyatakan likuiditas dan struktut aktiva secara bersama-sama berpengaruh signifikan terhadap struktur modal diterima atau terbukti. Jadi variabel likuiditas dan struktur aktiva secara bersama-sama (simultan) memiliki pengaruh signifikan terhadap struktur modal.

\subsection{Saran}

Berdasarkan keterbatasan di atas yang mungkin memberikan pengaruh terhadap hasil penelitian ini maka penulis memberikan beberapa rekomendasi untuk penelitian selanjutnya, antara lain adalah sebagai berikut:

1. Penelitian selanjutnya diharapkan dapat memperpanjang tahun penelitian artinya lebih dari lima tahun.

2. Penelitian selanjutnya diharapkan dapat memperluas ruang lingkup penelitian agar lebih menggambarkan secara keseluruhan perusahaan yang terdaftar di Bursa Efek Indonesia baik perusahaan keuangan maupun non keuangan

3. Penelitian selanjutnya dapat menambahkan variabel lain yang mempengaruhi struktur modal perusahaan seperti profitabilitas, ukuran perusahaan, non-debt tax shields, kesempatan pertumbuhan, volatilitas laba dan dividen, umur perusahaan, time interest earned, dan free cash flow.

4. Penelitian selanjutnya dapat menambah jumlah sampel dan tahun penelitian untuk menghindari terjadi masalah heteroskedastisitas.

\section{DAFTAR PUSTAKA}

Alzomaia, Turki S.F. 2014. Capital Structur Determinant Of Publicly Listed Companies in Saudi Arabia. The Internasional Journal of Business and Finance research, Vol. 8. 2: 53-67

Christianti, Ari. 2006. Penentuan Perilaku Kebijakan Struktur Modal pada Perusahaan Manufaktur di Bursa Efek Jakarta: Hipotesis Static trade off atau Pecking Order Theory. Simposium Nasional Akuntansi 9 Padang. Hal: 1-18.

Cortez, Michael Angelo dan Stevie Susanto. 2012. The Determinants of Corporate Capital Strucuture: Evidense From Japanese Manufakturing Companies. Jurnal of International business research, Vol. 11, Special Issue, No. 3:121-134.

Firnanti, Friska. 2011. Faktor-Faktor yang Mempengaruhi Struktur Modal Perusahaan Manufaktur di Bursa Efek Indonesia. Jurnal Bisnis dan Akuntansi, Vol. 13, No. 2: 119128.

Ghozali, Imam. 2013. Aplikasi analisis multivariate dengan program IBM SPSS 21 Update PLS Regresi. Edisi 7. Badan Penerbit Universitas Diponegoro. Semarang.

Gitman, Lawrence J. dan Chad J, Zutter. 2012. Principle of Managerial Fiance Thirteen Edition. England: Pearson Education, Inc.

Godfrey, Jayne., Allan Hodgson., Ann Tarca., Jane Hamilton dan Scott Holmes. 2010. Accounting Theory, $7^{\text {th }}$ Edition.

Hair, Joseph F, Jr., William C. Black, Barry J. Babin dan Rolph E. Anderson. 2010. Multivariate Data Analysis a Global Perspective. Seventh edision. U. S. A.: Pearson Edication, Inc.

Hidayat, Riza Fatoni dan Sudarno. 2013. Analisis Faktor-Faktor yang Mempengaruhi Struktur Modal Pada Perusahaan Manufaktur Terdaftar Di Bursa Efek Indonesia Periode 20072011. Diponegoro Journal Of Accounting. Vol. 2, No. 2.

Joni dan Lina. Faktor-Factor Yang Mempengaruhi Struktur Modal. 2010. Jurnal Bisnis dan Akuntansi, V. 12, No.2: 81-96. 
Kiran, Samra. 2013. Determinants of Capital Structure: A Comparative Analysis of Textile, Chemical \& Fuel and Energy Sectors of Pakistan. International Review of Management andBusiness Research, Vol. 2 Issue. 1, 37-47.

Margaretha, Farah dan Aditya Rizky Ramadhan. 2010. Faktor-Faktor Yang Mempengaruhi Struktur Modal Pada Industri Manufaktur di Bursa Efek Indonesia. Jurnal Bisnis dan Akuntansi, Vol. 12, No. 2: 119-130.

Masnoon, Maryam Farukh Anwar. 2012. Capital Structure Determinants of KSE Listed Pharmaceutical Companies. Global Management Journal For Academic \& CorporateStudies, Vol. 2, No. 1: 19-38.

Nuswandari, Cahyani. 2013. Determinan Struktur Modal Dalam Perspektif Pecking Order Theory Dan Agency Theory. Dinamika Akuntansi, Keuangan dan Perbankkan. Vol. 2, No. 1, Hal. 92-102.

Santoso, Singgih. 2014. Statistik Parametik. Edisi Revisi. PT Elex Media Komputindo. Jakarta

Seftianne dan Ratih Handayani. 2011. Faktor-Faktor yang mempengaruhi struktur modal pada perusahaan publik sektor manufaktur. Jurnal Bisnisdan Akuntansi, Vol. 13, No. 1:39-56.

Sekaran, Uma dan Roger Bougie. 2013. Research Methods for Business. Sixth Edition. United Kingdom: John Wiley \& Sons Ltd.

Setiana, Esa dan Desy Rahayu. 2012. Analisis Pengaruh Struktur Modal Terhadap Kinerja Pada Perusahaan Otomotif Yang Terdaftar Di BEI Tahun 2008-2010. Jurnal Telaah Akuntansi. Vol. 13. No. 1.

Setiawati, Rike. 2011. Faktor-FAktor yang Mempengaruhi Struktur Modal (Survey Pada Perusahaan Sanitaer di Kota Jambi). Jurnal Managemen Keuangan dan Portofolio. Vol. 1, No. 1.

Sheikh, Nadeem Ahmed dan Zongjun Wang. 2011. Determinants of Capital Structure: An Empirical Study of Firms In Manufacturing Industry of Pakistan. Managerial Finance, Vol. 37, No. 2: 117-133.

Umer, Usman Muhammed. 2014. Determinant of Capital Structure: Empirical Evidence from Large Taxpayer Share Companies in Ethiopia. International Journal of Economics and Finance, Vol. 6, No. 1: 53-65.

Wimelda, Linda dan Aan Marlinah. 2013. Variabel-Variabel yang Mempengaruhi Struktur Modal pada Perusahaan Publik Sektor Non Keuangan. Media Bisnis, Edisi khusus November. 
